The Canadian Journal of Higher Education

La revue canadienne d'enseignement superieur

Volume XXVII-1, 1997, pages 1-24

\title{
Place of Residence, Student Involvement, and First Year Marks
}

\section{J. PAUL GRAYSON}

Institute for Social Research, York University

\section{Abstract}

Research conducted in the United States has shown that students living in residence have greater gains in areas such as intellectual development, and are more likely to stay in university and complete their degrees, than students who live off-campus. The enhanced student involvement of those in residence is often cited in explanation for positive outcomes such as these. While there are some dissenting voices, research has also demonstrated that place of residence has little, if any, impact on marks. In a study of York University, a large commuter university, it is shown that place of residence does affect student involvement and first year marks; however, after controlling for OAC marks and faculty of enrollment, the first year marks of students who live at home with parents are higher than those of students in residence. Part of the explanation for this phenomenon can be found in the fact that despite their place of residence off-campus and low involvement in some activities, students living with their parents have higher rates of classroom involvement than students living in residence. In essence, living off-campus with parents does not represent a disadvantage in terms of first year marks.

The author thanks Danny Spitali for providing information on York's residences and Linda Grayson, Michael Ornstein, and two anonymous reviewers for helpful comments made on an earlier version of this article. 


\section{Résumé}

Une recherche effectuée aux États-unis a montré que les étudiants vivant en résidence retirent davantage, notamment sur le plan du développement intellectuel, et sont plus susceptibles de terminer leurs études universitaires que ceaux qui demeurent à l'extérieur du campus. On explique souvent ces résultats positifs par la forte participation de ces étudiants à la vie universitaire. En dépit de certains avis divergents, la recherche a aussi montré que le lieu de résidence a peu ou pas d'influence sur les notes des étudiants. Une étude sur l'université York, où un grand nombre d'étudiants vivent hors campus, a montré que le lieu de résidence influe sur la participation et sur les notes de première année. Toutefois, après avoir contrôle les notes obtenues par les étudiants au CPO et la faculté à laquelle ils étaient inscrits, il a été possible d'observer que les notes des étudiants de première année qui vivaient chez leurs parents étaient plus élevées que celles de ceux qui vivaent en résidence. Cette constatation peur en partie s'expliquer par le fait que, malgré leur lieu de résidence et leur faible participation à certaines activités, les étudiants vivant chez leurs parents présentent un taux de participation en classe plus élevé que leurs collègues vivant en résidence. Essentiellement, le fait de vivre au domicile familial ne représente pas un désavantage eu égard aux notes obtenues en première année.

\section{Introduction}

In Canada it is difficult to estimate the numbers of students who live on and off campuses.' While at some institutions, such as Mount Allison and Queen's, residence living in first year is the norm, information on other universities indicates that large numbers of first year students live with their parents. For example, a first year study at the University of Alberta found that two-thirds of students lived at home with their parents (Holdaway \& Kelloway, 1987, p. 60). The figures for the University of Manitoba (University of Manitoba, Sept. 1991), the University of Victoria (University of Victoria, 1992), and Dalhousie (Christie, 1988) are $66 \%, 61 \%$, and $42 \%$ respectively. At York University, in 1995 , approximately $74 \%$ of first year students reported living at home with their parents, while only $15 \%$ lived on campus. The remaining $11 \%$ lived 
in other arrangements. For students living off campus, on average, it took 45 minutes to commute one way to the university.

In survey data collected by the University of Guelph in 1993 on first year students in seven universities just prior to, or at the beginning of, classes in September it was found that $56 \%$ would be or were living at home with parents. Interestingly, only $28 \%$ specified this as their preferred living arrangement. The most desired living location was on-campus; however, while $36 \%$ of students identified on-campus living as their first choice, only $28 \%$ actually expected to be in residence on campus. ${ }^{2}$

In the United States a great deal of research has been done on the consequences of living on and off campus. ${ }^{3}$ While there are contrary findings, in general, living on or near campus has been found to have a positive impact on desired outcomes of the university experience. As Pascarella and Terenzini summarize:

Residential living is positively, if modestly, linked to increases in aesthetic, cultural, and intellectual values; a liberalizing of social, political, and religious values and attitudes; increases in self-concept, intellectual orientation, autonomy, and independence; gains in tolerance, empathy, and ability to relate to others; persistence in college; and bachelor's degree attainment (1991, p. 611).

The reason for the positive influence of residence living on factors such as the above is related to the notion of student involvement (Astin, 1985 , p. 133). As Kuh elaborates with regard to this concept, "the more time and energy students expend in educationally purposeful activities, the more they benefit" (1995, p. 125). In theory, students living on-campus have greater opportunities than commuters to involve themselves in the social, cultural, curricular, and extra-curricular activities of the institution. It is through involvement such as this that students become socialized to academic values and engage themselves in the activities that lead to desired outcomes such as cognitive development, retention, and the acquisition of subject matter expertise (Astin, 1993).

Despite potential positive effects such as these, Pascarella and Terenzini (1980) found that some residences contribute to intellectual growth more than others. Indeed, the climate in some residences may be 
inimical to growth and academic achievement. More importantly, a literature review found some studies indicating that despite its potential positive effects, in general, residence living has little effect on academic achievement (Bowman \& Partin, 1993; Pascarella \& Terenzini, 1991). There are, however, exceptions to this rule. Within residences, the establishment of special study floors with required quiet-times (Blimling \& Hemple, 1979), the utilization of skilled tutors in residences (Taylor, Roth \& Hanson, 1971), and the establishment of living-learning centres intended to integrate residential and academic life (Pascarella \& Terenzini, 1981) have been found to have small positive impacts on achievement.

The little research conducted in Canada on the effects of residence living is consistent with some general conclusions of studies carried out in the United States. For example, in a survey conducted at the University of Manitoba (University of Manitoba, 1990), it was found that while $53.4 \%$ of first year students in residence were satisfied with their intellectual development since enrolling, the figure for those not in residence was only $41.4 \%$. At Trent University, residence students were more likely than commuter students to highly rate a number of their college experiences (Wong, 1994). To date, however, the relationship between living in residence and academic achievement remains virtually unstudied. What is known is that in Canadian universities there is little integration of academic matters into residence life (Carson, DuPlessis \& Mighty, 1995).

As universities strive to create optimal learning environments for their students, it is important for each institution to know if those living on or off campus are advantaged or disadvantaged in terms of specified outcomes of the university experience. Research into matters such as these may facilitate the development and implementation of institutionally specific policies designed to ameliorate any negative effects of residence location. Consistent with this objective, the current article focuses on the effects of residence location on student involvement and the relationship of the latter to grade point averages of first year students at York University. 


\section{Orientation to Research}

In examining the impact of residence location on grades, it is helpful to utilize the general logic of the 'input-environment-outcome' (I-E-O) model as developed by Astin (1993, p. 7). While the general model has many variants, in brief, "inputs refer to the characteristics of the student at the time of initial entry to the institution; environment refers to the various programs, policies, faculty, peers, and educational experiences to which the student is exposed; and outcome refers to the student's characteristics after exposure to the environment" (p. 7). In the case at hand the intent is to determine whether after adjusting for background variables (inputs), and faculty of enrollment (environment), living in residence (environment) contributes to student involvement (environment) and results in higher grade point averages (GPA) (outcome) than for students living at home with parents (environment). The general connections involved are expressed in Figure 1.

In the current analysis, input variables were family income, gender, Ontario Academic Credit (OAC) marks, and age. ${ }^{4}$ The environmental variables falling in an 'academic involvement' category that were examined included: number of contacts with faculty, teaching assistants, and staff (Contacts); and frequency of class/tutorial/lab attendance and number of visits to the library (Classroom Involvement). Measures of 'social involvement' included: number of clubs and/or organizations belonged to (Club Involvement); participation in cultural activities (Cultural Involvement); number of new friends, time spent with new friends, and visits to campus pubs (Social Involvement); and participation in sports and exercise activities (Sports Involvement). Measures of academic and social involvement were based on the average $z$-score calculated across all students in the survey for the relevant items. ${ }^{5}$ Actual questions used in the construction of the indexes are outlined in Appendix A. In other analyses it has been found that in commuter institutions such as York, academic involvement is related to high marks (Grayson, 1994, 1995). 


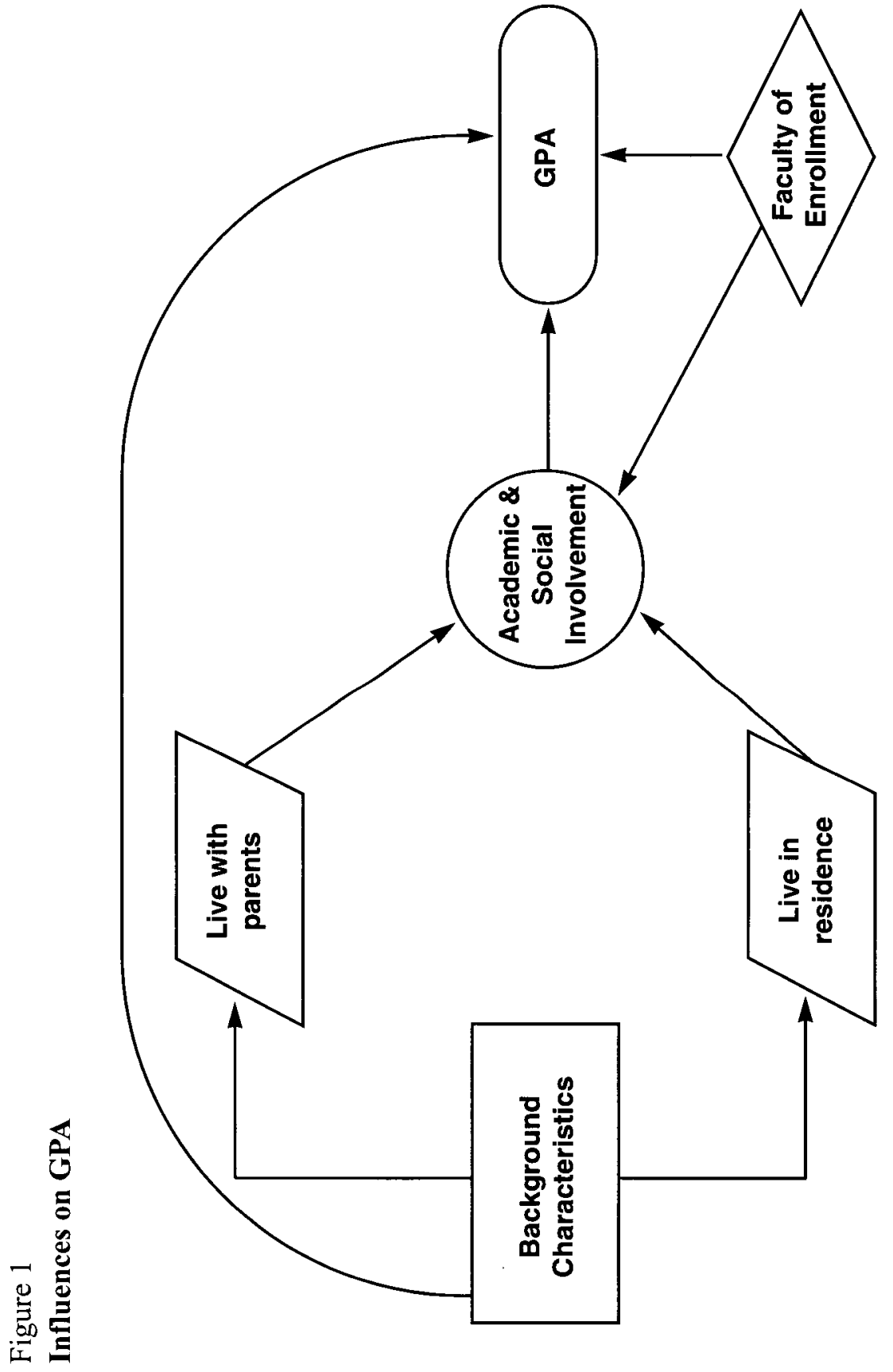

Canadian Joumal of Higher Education

Vol. XXVII-1, 1997 


\section{York University}

York University, with approximately 43,000 students, ${ }^{6}$ is located on the northern fringe of Metropolitan Toronto. While single and multiple family dwellings can be found to the west and south of the campus, commercial and industrial establishments characterize development to the east. The area to the immediate north of the campus is only partially developed. On average, surveys show that first year students not living on campus spend 1.5 hours commuting to and from the university.

\section{Data Sources}

Information on student involvement, residence location, and first year grades was obtained from two sources. The first was a 1995 end-of-year mail survey of 1,848 full-time first year students in all faculties designed to obtain information on various aspects of the first year experience such as academic and social involvement, problems faced in the first year of study, and satisfaction with various aspects of the educational experience. The response rate to the survey was approximately $65 \%$. The second source of data, administrative records, was utilized primarily for Ontario Academic Credit marks (OACs) and first year grade point averages (GPAs). Data from both sources were merged into a single file.

\section{Place of Residence and Student Involvement}

The living arrangements for first year York students was obtained from the mail survey. Overall, the largest single number of students, $74 \%$, live at home with their parents. A further $10 \%$ and $5 \%$ live in double and single residence rooms respectively. Three percent live with a spouse, $2 \%$ off-campus alone, and 3\% off-campus with a friend. Of the remaining students, $1 \%$ were in temporary living arrangements and $2 \%$ listed 'other' as their residence.

In a recent study of residences in Canadian universities Carson, DuPlessis and Mighty (1995) found that for most institutions there were few links between formal academic activities and residence life. From the way in which their data are presented, it is not possible to determine 
if York was one of the institutions responding to the study. As a result, it is impossible to say if linkages between formal academic activities and residence life are above or below the norm. What is known is that at York various colleges associated with residences offer courses on study and critical skills and sponsor various events like lecture series, field trips, and book launchings. Participation in such activities, however, is not restricted to students living in residence. ${ }^{7}$

Because of space constraints it is not possible to examine the implications of all residence possibilities outlined above. Moreover, differences among those living with a spouse, off-campus alone, off-campus with a friend, or in temporary arrangements are too large to warrant combining these groups into an 'other' category. As a result, 'others' will be dealt with elsewhere and attention will focus on comparisons among students who live at home with parents and those in double and single residence rooms.

\section{Background (Input) Variables}

Tables 1 and 2 deal with differences between students who live with parents and in residence along the input, environmental, and outcome variables included in the I-E-O model discussed above. Data in Table 1 indicate a slight relationship between annual family income and living in residence. For example, among students reporting family incomes up to $\$ 25,999,15.9 \%(10.3 \%+5.6 \%)$ report living in residence. For students whose families are in the $\$ 100,000+$ category, $24.5 \%(14.9 \%+9.6 \%)$ report residence living. Differences, however, are not statistically significant. Information in Table 1 also indicates that females (24.0\%) are more likely than males (16.8\%) to live in residence and the differences are statistically significant.

Information on the remaining two background variables, age and OAC marks, is found in Table 2. While the average age of students living at home and in double residence rooms is 20 , those who live in single residence rooms report an average age of 21 ; moreover, although slight, this difference is statistically significant. The slightly older age of students in single rooms may indicate that such students have not come to university directly from high school. 
Table 1

Residence Location by Family Income and Gender

\begin{tabular}{llrrrrr}
\hline & & \multicolumn{3}{c}{ Residence Location } & \multicolumn{2}{c}{ Total } \\
\cline { 3 - 5 } & & $\begin{array}{c}\text { With } \\
\text { parents }\end{array}$ & $\begin{array}{c}\text { Residence Residence } \\
\text { double }\end{array}$ & single & Row \% & Count \\
\hline Family & to $\$ 24,999$ & $84.1 \%$ & $10.3 \%$ & $5.6 \%$ & $100.0 \%$ & 195 \\
Income $^{\mathrm{a}}$ & $\$ 25,000$ to $\$ 49,999$ & $82.8 \%$ & $10.9 \%$ & $6.3 \%$ & $100.0 \%$ & 331 \\
& $\$ 50,000$ to $\$ 74,999$ & $77.0 \%$ & $14.4 \%$ & $8.5 \%$ & $100.0 \%$ & 305 \\
& $\$ 75,000$ to $\$ 99,999$ & $75.9 \%$ & $16.8 \%$ & $7.3 \%$ & $100.0 \%$ & 137 \\
& $\$ 100,000+$ & $75.5 \%$ & $14.9 \%$ & $9.6 \%$ & $100.0 \%$ & 583 \\
Total & & $78.5 \%$ & $13.5 \%$ & $8.0 \%$ & $100.0 \%$ & 1,551 \\
Gender & Female & $76.0 \%$ & $15.5 \%$ & $8.5 \%$ & $100.0 \%$ & 1,035 \\
& Male & $83.2 \%$ & $9.6 \%$ & $7.2 \%$ & $100.0 \%$ & 570 \\
Total & $78.6 \%$ & $13.4 \%$ & $8.0 \%$ & $100.0 \%$ & 1,605 \\
\hline a Chi-square sig. .136 & & & & & \\
b Chi-square sig. .002 & & & & & \\
\hline
\end{tabular}

If OAC marks are examined it can be seen that those of students in double residence rooms are slightly higher (80.63) than those of students living with parents (79.11) and in single rooms (79.04). Although statistically significant, these differences are very small.

\section{Environment Variables}

Table 2 also contains information on various forms of student involvement. With one exception (hours per course), differences for all measures of involvement are statistically significant.

Because the standardized score for contacts with faculty andstaff for students living in double rooms (-.14) is lower than for students living with parents (-.06), it is clear that living on-campus does not result in involvement with faculty and staff; however, the score for students living in single rooms is higher than that of the other two groups (.12). The low contact rate for double room occupants may be explained by the possibility that students living in double rooms rely for support more on their room-mates than on faculty and staff. 


\section{Table 2}

OAC Marks, Student Involvement, and GPA by Residence Location

\begin{tabular}{|c|c|c|c|c|c|}
\hline & & Res & dence Loc: & ation & \\
\hline & & $\begin{array}{c}\text { With } \\
\text { parents }\end{array}$ & $\begin{array}{c}\text { Residence } \\
\text { double }\end{array}$ & $\begin{array}{l}\text { Residence } \\
\text { single }\end{array}$ & $\underset{\text { total }}{\text { Group }}$ \\
\hline Age (F sig .001) & Mean & 20 & 20 & 21 & 20 \\
\hline & Std Deviation & 1 & 1 & 3 & 1 \\
\hline $\mathrm{OAC}(\mathrm{F}$ sig .007) & Mean & 79.11 & 80.63 & 79.04 & 79.30 \\
\hline & Std Deviation & 6.22 & 6.23 & 7.37 & 6.32 \\
\hline Contacts faculty, & Mean & -.06 & -.14 & .12 & -.06 \\
\hline staff, TAs (F sig .003) & Std Deviation & .64 & .50 & .74 & .63 \\
\hline Club involvement & Mean & -.04 & .04 & .23 & -.01 \\
\hline$(\mathrm{F} \operatorname{sig} .013)$ & Std Deviation & .97 & 1.06 & 1.14 & 1.00 \\
\hline Cultural involvement & Mean & -.20 & .79 & .44 & -.01 \\
\hline (F sig .000) & Std Deviation & .70 & 1.07 & .93 & .86 \\
\hline Social involvement & Mean & -.18 & 1.00 & .76 & .03 \\
\hline$(\mathrm{F}$ sig .000) & Std Deviation & .61 & .77 & .82 & .78 \\
\hline Sports involvement & Mean & -.13 & .53 & .62 & .02 \\
\hline (F sig .001) & Std Deviation & .60 & 1.04 & 1.12 & .79 \\
\hline Classroom involvement & Mean & .06 & -.11 & -.18 & .02 \\
\hline (F sig .000) & Std Deviation & .66 & .60 & .65 & .66 \\
\hline Hours per course & Mean & 5.62 & 5.07 & 5.75 & 5.56 \\
\hline (F sig .304) & Std Deviation & 5.03 & 4.29 & 4.46 & 4.90 \\
\hline GPA (F sig .755) & Mean & 5.44 & 5.51 & 5.52 & 5.46 \\
\hline & Std Deviation & 1.67 & 1.52 & 1.65 & 1.65 \\
\hline & Total Count & 1,271 & 215 & 129 & 1,615 \\
\hline
\end{tabular}


If club involvement is examined it is evident that double and single room occupants are more involved (.04 and .23 respectively) than those living at home (-.04). Once again, however, the involvement rate for students in single rooms is higher than that of students sharing a room. For cultural involvement on campus, highest rates are reported by students in double rooms (.79), the lowest by students living at home $(-.20)$, with students in single rooms occupying the middle position (.44). The same pattern is repeated for social involvement. Students living at home have the lowest score $(-.18)$ while those in double rooms have the highest (1.0). Individuals in single rooms fall in between (.76). For sports involvement, students living with parents score the lowest (-.13) and the highest levels of involvement are reported by students with single rooms (.62) Those in double rooms occupy a middle position (.53).

Although it might be thought that living on campus would facilitate classroom involvement, table data indicate that the greatest involvement in this area (.06) is on the part of students living with parents. In other words, they go to class and the library more frequently than those in double rooms (-.11) and students living in single rooms (-.18). Although differences are not statistically significant, students in single rooms spend 5.75 hours per week per course studying outside of class whereas students living at home and in double rooms spend 5.62 and 5.07 hours respectively.

Although on a course-by-course basis students spend roughly an equal amount of time on their studies no matter what their place of residence, those living at home work for pay an average of 8.9 hours per week while the figures for students in double and single rooms are only 3.3 and 4.2 hours respectively (not shown in table) (differences are statistically significant at the .000 level). What is important for the current analysis, however, is not the number of hours spent in paid employment, but the amount of time devoted to study. This point will be reflected in a later regression analysis.

\section{Outcomes}

With regard to grade point averages as obtained from administrative records, there are slight differences among students who live at home 
(5.44), students in double rooms (5.51); and those in single rooms (5.52); however, differences are neither large nor statistically significant.

\section{Conclusion}

In general, students living in residence come from slightly more affluent families than those living at home and more female than male students live on campus. In addition, overall, students living in residence tend to be more involved in various activities than those who live with their parents. For example, the average z-score for contacts with faculty and staff, club involvement, cultural involvement, social involvement, and sports involvement is -.12 for students living with parents, and .44 and .43 for those living in double and single rooms respectively. Put differently, the average involvement scores calculated this way for students in double and single rooms are 22 percentile points higher than those living with parents. Nonetheless, on individual items, there are differences between the involvement rates of students in double and single rooms. More importantly, when it comes to classroom involvement (not included in the above means) students living at home are more active than those in residence.

\section{Place of Residence, Student Involvement, and GPA}

Before examining more complex relationships among place of residence, student involvement, and GPA, it is necessary to look at connections between faculty of enrolment, residence location, and grades. Information in Table 3 indicates that places of residence vary considerably with faculty of enrolment. Although in this article attention is focused on students living with parents or in residence, those living in other arrangements also have been presented in the table to facilitate a global view of living arrangements within faculties.

Fine Arts has the fewest number of students (56.6\%) living with parents while Administrative Studies (92.7\%) has the greatest number living at home. Similarly, both Fine Arts and Glendon College ${ }^{8}$ have the greatest number of students living in double and single residences $-43.4 \%$ and $40.4 \%$. By way of contrast, only $7.3 \%$ of Administrative Studies 
Table 3

\section{Residence Location by Faculty}

\begin{tabular}{llrrrrr}
\hline & & \multicolumn{3}{c}{ Residence Location } & & \multicolumn{2}{c}{ Total } \\
\cline { 3 - 5 } & & $\begin{array}{c}\text { With } \\
\text { parents }\end{array}$ & $\begin{array}{c}\text { Residence } \\
\text { double }\end{array}$ & single & Row \% & Count \\
\hline Faculty & Env. Studies & $85.1 \%$ & $10.4 \%$ & $4.5 \%$ & $100.0 \%$ & 67 \\
& Fine Arts & $56.6 \%$ & $36.0 \%$ & $7.4 \%$ & $100.0 \%$ & 272 \\
& Admin. Studies & $92.7 \%$ & $6.3 \%$ & $1.0 \%$ & $100.0 \%$ & 96 \\
& Science & $85.6 \%$ & $8.6 \%$ & $5.8 \%$ & $100.0 \%$ & 327 \\
& Arts & $88.8 \%$ & $8.5 \%$ & $2.7 \%$ & $100.0 \%$ & 625 \\
& Glendon & $59.6 \%$ & $10.1 \%$ & $30.3 \%$ & $100.0 \%$ & 228 \\
Total & & $78.7 \%$ & $13.3 \%$ & $8.0 \%$ & $100.0 \%$ & 1,615 \\
\hline a Chi-square sig. .000 & & & & & \\
\hline
\end{tabular}

students report living in residence. The figures for Science, Environmental Studies, and Arts are $14.4 \%, 14.9 \%$, and $11.2 \%$ respectively.

As seen in Table 4, average OAC marks and GPAs vary considerably by faculty. For example, the highest OAC marks and GPAs, 87.37\% and 7.01 respectively, are achieved by students in Administrative Studies. The lowest OACs, $76.78 \%$, are found among Glendon students; however, Science students score the lowest average GPA, 4.92 .

Because students in different faculties achieved different average OACs and GPAs, and because faculties vary in the percentage of their students in different living arrangements, as well as controlling for background and environmental variables discussed earlier, it is necessary to control for faculty of enrolment when assessing the impact of residence location on student involvement and GPA. For example, students in Administrative Studies have both the highest OAC marks and GPAs. Also, more live at home than students in other faculties. As a result, care must be taken not to attribute the high GPAs of business students to their living at home or to background or other environmental variables when in fact high marks may be a result of students' high OACs and/or their participating in the Administrative Studies program. The required 
Table 4

OAC Marks and GPA by Faculty

\begin{tabular}{|c|c|c|c|c|c|c|c|c|}
\hline & & \multicolumn{6}{|c|}{ Faculty } & \multirow[b]{2}{*}{$\begin{array}{l}\text { Group } \\
\text { Total }\end{array}$} \\
\hline & & $\begin{array}{c}\text { Environ. } \\
\text { Studies }\end{array}$ & $\begin{array}{l}\text { Fine } \\
\text { Arts }\end{array}$ & $\begin{array}{l}\text { Admin. } \\
\text { Studies }\end{array}$ & Science & Arts & Glendon & \\
\hline \multirow[t]{2}{*}{$\mathrm{OAC}$} & Mean & 80.69 & 79.94 & 87.37 & 80.41 & 77.60 & 76.78 & 79.19 \\
\hline & Std Dev. & 4.84 & 5.90 & 3.34 & 6.40 & 5.47 & 6.81 & 6.31 \\
\hline \multirow[t]{3}{*}{ GPA } & Mean & 6.00 & 5.85 & 7.01 & 4.92 & 5.19 & 5.54 & 5.44 \\
\hline & Std Dev & 1.49 & 1.39 & 1.10 & 1.93 & 1.58 & 1.57 & 1.68 \\
\hline & $\begin{array}{l}\text { Total } \\
\text { Count }\end{array}$ & 73 & 328 & 109 & 384 & 701 & 269 & 1,864 \\
\hline
\end{tabular}

F significant at .000 level for $\mathrm{OAC}$ and GPA

control of background and environmental variables and faculty of enrolment can be achieved through analysis of covariance.

Once adjustments have been made for OAC marks and faculty of enrollment, differences in grade point average among students living at home (5.50), and in double (5.19) or single (5.38) residence rooms are statistically significant ( $\mathrm{F}$ sig. at .000 level). In essence, although students in residence are more involved in certain aspects of the university than students who live at home, their first year marks are slightly lower than those of students living at home.

An explanation for this finding can be found in Table 5 that summarizes the results of a regression analysis in which GPA is the dependent variable and the background, environmental, and faculty variables used in previous analyses are the independent variables. This time residence location is represented by two dummy variables, DOUBLE (double room) and SINGLE (single room) with living at home with parents as the reference category. Similarly, dummy variables have been created for faculty of enrollment (ES = Environmental Studies, FA = Fine Arts, AS $=$ Administrative Studies, $\mathrm{SCI}=$ Science, GLENDON $=$ Glendon College) with Arts as the reference category. Gender is coded 0 for 
Table 5

Regression Analysis for GPA

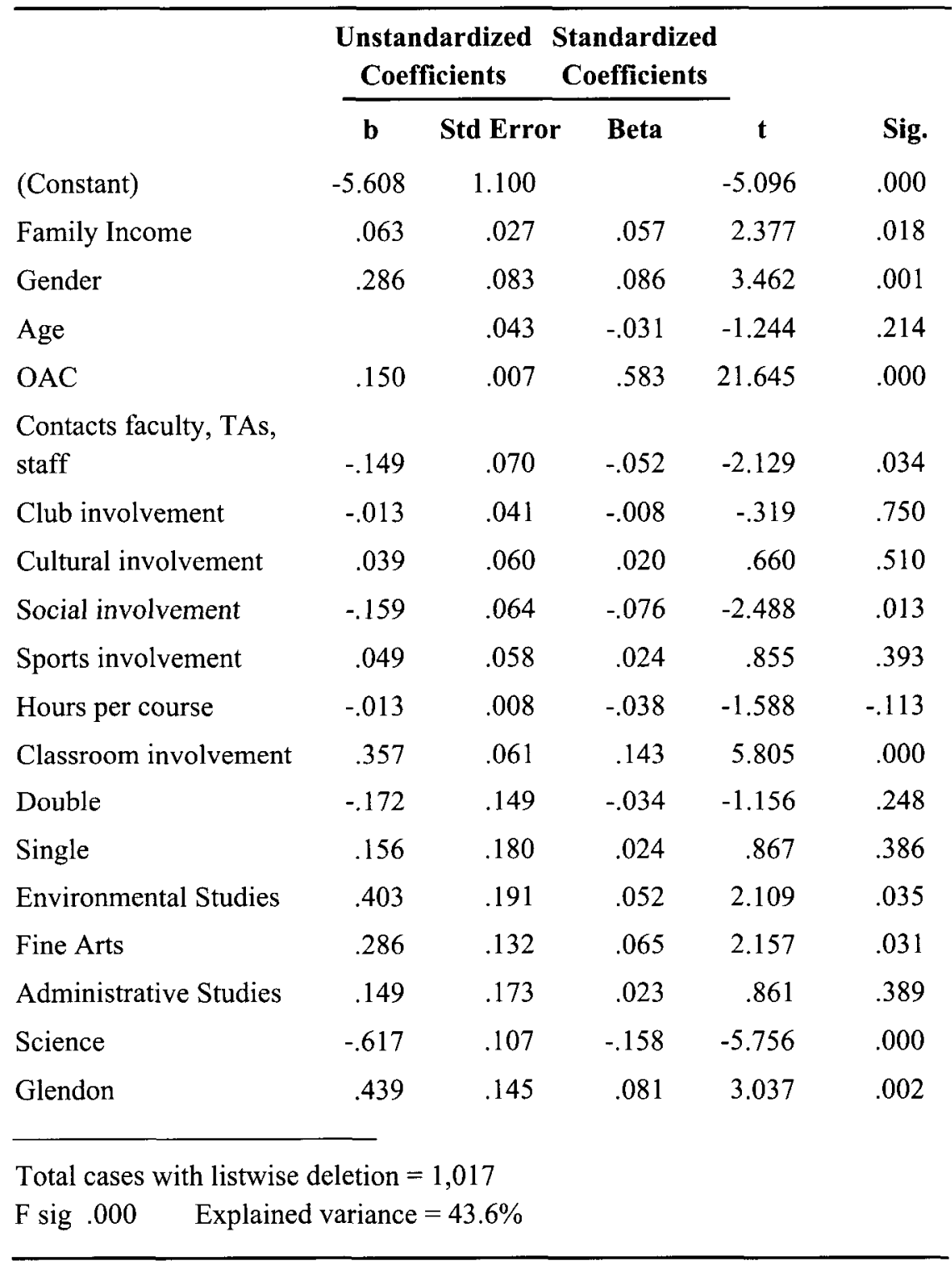


College) with Arts as the reference category. Gender is coded 0 for female and 1 for male.

Overall, to concentrate on background and environmental variables, table data indicate positive and statistically significant relationships between family income, gender (being male), OAC marks, and classroom involvement. Of these variables, with betas of .583 and .143 respectively, OAC marks and classroom involvement are most important in explaining GPA. Cultural and sports involvement also have slight positive but statistically insignificant impacts on GPA.

There are negative and statistically significant relationships between GPA and contacts with faculty etc. and social involvement. Betas for each, -.052 and -.076, are small. Small, negative and statistically insignificant relationships are also found between GPA and age, club involvement, and hours per course spent on studies. While the last mentioned may seem counter-intuitive, it is consistent with the possibility that students with low academic aptitude may be required to spend more time on studies than those with high aptitude. In view of the focus of the current study, it is important to note that living in neither a double nor a single residence room affects GPA to a statistically significant extent.

In terms of faculty of enrollment, table data indicate that being in the faculties of Environmental Studies, Fine Arts, and Glendon College contributes positively to GPA at a statistically significant level whereas being enrolled in Science has the opposite effect. Overall, the model in Table 5 explains $43.6 \%$ of the total variance in GPA.

The contribution of various forms of involvement to GPA was determined in two steps. First, classroom involvement was removed from the regression. Second, all of the other involvement variables were removed. As a result of the first step the explained variance decreased to $41.0 \%$. In essence, classroom involvement explained $2.6 \%(43.6 \%-41.0 \%)$ of the total variance. Removing the additional involvement variables further reduced the explained variance one percentage point to $40.0 \%$. Whereas the single classroom involvement variable accounted for $2.6 \%$ of the variance, all of the remaining involvement variables explained only $1 \%$ of the variance in GPA. While these figures suggest that classroom involvement is far more important than other forms of involvement, they 
also indicate that overall various forms of involvement contribute little to explanations of GPA.

Despite this qualification, as the primary concern in this article is to examine the extent to which different residence locations contribute to social involvement and grades, an analysis of covariance was carried out to assess the differences in classroom involvement for students living at home and in residence controlling for background and environment variables and faculty of enrollment. ${ }^{9}$ When this was done it was found that the standardized scores for students at home and in double and single rooms in residence were $.06,-.17$, and -.03 respectively (these values differ from the unadjusted scores in Table 2). In essence, the difference between students living at home and those living in double and single rooms represents 9 and 1 percentile points respectively. Clearly, students living at home with parents are not disadvantaged in term of classroom involvement.

\section{Conclusion}

In the introduction it was seen that data collected at the University of Guelph indicates that the single most preferred place of residence for first year students was on campus. While some students may be attracted to residence life in anticipation of a high quality social life, others are no doubt equally, if not more, concerned with the convenience of residence living and the expectation that living on campus will allow them to take full advantage of university offerings.

From the data collected for this study, there is no doubt that in general students living in residence are involved in more out-of-class activities than those living at home. Despite this, the first year grades of residence students are slightly lower than those of students living with parents. A part of the explanation for this phenomenon is that although the latter have overall lower levels of involvement in many activities than residence students, in the critical area of classroom involvement they rank higher than particularly students living in double residence rooms.

Whether or not the same differences would be found at York for other outcomes such as intellectual development or retention is beyond the scope of the current article. Moreover, it is not known if similar patterns 
would be found in other Canadian universities or if the effects observed at York, a commuter university, would characterize campuses on which the majority of first year students live in residence. Finally, it is hard to say whether or not the introduction of, for example, living-learning centres that would attempt to bridge academic and residence life more effectively than currently is the case, would lead to increased achievement on the part of first-year York students. What is clear is that living at home with parents does not detract from first year academic achievement. At a large commuter university like York this is encouraging news. It suggests that one very important objective of many students, getting good marks, is not jeopardized by living with parents off-campus.

\section{References}

Anderson, K. (1981). Post-high school experiences and college attrition. Sociology of Education, 54, 1-15.

Astin, A. (1985). Achieving educational excellence: A critical assessment of priorities and practices in higher education. San Francisco, CA: Jossey-Bass. Astin, A. (1993). What matters in college. San Francisco, CA: Jossey-Bass. Blimling, G., \& Hemple, D. (1979). Structuring the peer environment in residence halls to increase academic performance in average-ability students. Journal of College Student Personnel, 20, 310-316.

Bowman, R.L., \& Partin, K.E. (1993). The relationship between living in residence halls and academic achievement. College Student Affairs Journal, 13(Fall), 215-233.

Braxton, J., \& Brier, E. (1989). Melding organizational and interactional theories of student attrition. Review of Higher Education, 13, 47-51.

Carson, A., DuPlessis, D., \& Mighty, E. (1995). Creating an academic culture: Issues in residence administration at institutions of higher education. The Canadian Journal of Higher Education, 25(2), 1-16.

Chickering, A. (1974). Commuting versus resident students. San Francisco, CA: Jossey-Bass.

Chickering, A., McDowell, J., \& Campagna, D. (1969). Institutional differences and student development. Journal of Educational Psychology, 60, 315-326.

Christie, B. (1988). Students' views on their undergraduate experience at Dalhousie. Halifax, NS: Dalhousie University. 
Fox, R. (1986). Application of a conceptual model of college withdrawal to disadvantaged students. American Educational Research Journal, 23, 415-424.

Grayson, J.P. (1994). First year science in a commuter university: Where to intervene. The Canadian Journal of Higher Education, 24(2), 16-42.

Grayson, J.P. (1995). The first generation at York University. Toronto, ON: Institute for Social Research, York University.

Herndon, S. (1984). Recent findings concerning the relative importance of housing to student retention. Journal of College and University Student Housing, 14, 27-31.

Holdaway, E., \& Kelloway, K. (1987). First year at university. The Canadian Journal of Higher Education, 17(1), 47-63.

Kuh, G. (1995). The other curriculum: Out-of-class experiences associated with student learning and personal development. The Journal of Higher Education, 66, 123-155.

Pace, C. (1984). Measuring the quality of college student experiences. Los Angeles, CA: University of California, Higher Education Research Institute.

Pascarella, E. (1985). The influence of on-campus living versus commuting to college on intellectual and interpersonal self-concept. Journal of College Student Personnel, 26, 292-299.

Pascarella, E. (1984). Reassessing the effects of living on-campus versus commuting to college. Review of Higher Education, 7, 247-260.

Pascarella, E., \& Terenzini, P. (1991). How college affects students. San Francisco, CA: Jossey-Bass.

Pascarella, E., \& Terenzini, P. (1981). Resident arrangement, student/faculty relationships, and freshman-year educational outcomes. Journal of College Student Personnel, 22, 147-156.

Pascarella, E., \& Terenzini, P. (1980). Student-faculty and student-peer relationships as mediators of the structural effects of undergraduate residence arrangement. Journal of Educational Research, 73, 344-353.

Schroeder, C., \& Belmonte, A. (1979). The influence of residential environment on prepharmacy student achievement and satisfaction. American Journal of Pharmaceutical Education, 43, 16-19.

Taylor, R., Roth, J., \& Hanson, G. (1971). Experimental housing and tutoring: Effects on achievement and attrition. Journal of College Student Personnel, $12,271-278$.

University of Manitoba. (1990, November). Student affairs report. Winnipeg, MB: University of Manitoba. 
University of Manitoba. (1991, September). Student affairs report. Winnipeg, MB: University of Manitoba

University of Victoria. (1992). Fall 1992 student experience questionnaire results. Victoria, BC: University of Victoria.

Velez, W. (1985). Finishing college. Sociology of Education, 58, 191-200.

Welty, J. (1976). Resident and commuter students. Journal of College Student Personnel, 17, 465-468.

Williamson, D., \& Creamer, D. (1988). Student attrition in 2- and 4- year colleges. Journal of College Student Development, 29, 210-217.

Wolfe, J. (1993). Institutional integration, academic success, and persistence of first-year commuter and resident students. Journal of College Student Development, 34, 253-270.

Wong, P. (1994). What's so good about Trent's college system? Peterborough, ON: Trent University. 


\section{Appendix A: Questions Used in Student Involvement Measures}

\section{Contacts}

8. Over the past two months, approximately how many contacts of ten minutes or more did you have with FACULTY MEMBERS, TEACHING ASSISTANTS, LAB DEMONSTRATORS, OR STUDIO TECHNICIANS outside of class for the following purposes. ('O' is a legitimate answer.)

Number of contacts 10 minutes or more over the past 2 months. (" 0 " is a legitimate answer. If you don't have TAs, etc., write NA for not applicable.)

\section{Reason for Contacts}

$\begin{array}{cc} & \text { TAs/Lab Demos/ } \\ \text { Faculty } & \text { Studio } \\ \text { (\# of connicians }\end{array}$

a) To help in resolving a disturbing personal problem ................

b) To socialize informally (having a coffee, having a beer, etc.)

c) To discuss a campus issue or problem ...

d) To discuss plans related to your future choice of occupation

e) To get basic information or advice about your academic program ............

f) To discuss course related problems, e.g., change of exam time, grade appeal, essay due date

g) To discuss intellectual matters

9. Over the last two months, approximately how many contacts of ten minutes or more have you had with university staff, such as secretaries, counsellors, student loan officers, etc.? (' 0 ' is a legitimate answer.) contacts 


\section{Classroom Involvement}

14. In an average week, what percentage of your lectures/ seminars do you attend? $\%$

15. In an average week, what percentage of your tutorials, labs, or studios do you attend? (Circle NA if not applicable.)

16. Over the past month how many times have you been to a library on campus? (' 0 ' is a legitimate answer.)

\section{Club Involvement}

2. How many campus organizations such as clubs or student councils do you belong to? (' 0 ' is a legitimate answer.)

\section{Cultural Involvement}

6. Since classes began in September, how many arts or cultural events have you been involved in, or performed in, on campus? (' $O$ ' is a legitimate answer.)

7. Since classes began in September, how many cultural events, films, concerts, or productions have you attended on campus? (' 0 ' is a legitimate answer.)

\section{Social Involvement}

8. On average, how many times a month do you visit campus pubs? (' 0 ' is a legitimate answer.)

9. Since enrolling at York, approximately how many new friends have you made? (' $O$ ' is a legitimate answer.)

10. In an average week, how many hours do you spend with the new friends you have made since you came to university? hrs.

\section{Sports Involvement}

3. How many organized sports (varsity, intramural) do you participate in on campus? (' 0 ' is a legitimate answer.)

4. In how many unorganized sports and/or exercise activities do you participate on campus? (' 0 ' is a legitimate answer.)

5. Since classes began in September, how many organized sports events have you watched on campus? (' 0 ' is a legitimate answer.) 


\section{Notes}

1 Pascarella and Terenzini (1991, p. 640) estimate that fewer than half of college/university students in the United States live on campus.

2 I would like to thank Brian Pettigrew at the University of Guelph for making these data available.

3 Examples include: Anderson, 1981; Bowman \& Partin, 1993; Braxton \& Brier, 1989; Chickering, 1974; Chickering et al., 1969; Fox, 1986; Herndon, 1984; Pace, 1984; Pascarella, 1984, 1985; Pascarella \& Terenzini, 1980, 1981; Schroeder \& Belmonte, 1979; Velez, 1985; Welty, 1976; Williamson \& Creamer, 1988; Wolfe, 1993.

4 The decision to include these background variables was guided by the fact that other research has found them to have independent effects on various first year outcomes (Astin, 1993; Pascarella \& Terenzini, 1991).

5 This procedure was followed because given the distributions of responses to various questions, averaging non-standardized scores would have resulted in undue emphasis being placed on certain activities.

6 Approximately 25,000 and 14,500 are full- and part-time undergraduates respectively. Roughly 3,500 are graduate students.

7 York has the fewest number of residence spaces per capita in Canada and first year demand exceeds supply. As in other universities, priority is given to scholarship students.

8 Glendon College is a small bilingual liberal arts college located approximately $20 \mathrm{~km}$ from the main campus.

9 On average, students attended $90 \%$ of their lectures (S.D. 19.4), 92\% of their tutorials, labs, or studios (S.D. 12.5), and visited a library on campus 8.8 times in the previous month (S.D. 7.8). 